Pomáhajúce profesie, roč. 4, č. 2, 2021, 22-30

\title{
JOB STRESSORS AND JOB SATISFACTION IN EMERGENCY MEDICAL SERVICES CREW MEMBERS IN SLOVAKIA
}

\author{
Martin Sedlár \\ Institute of Experimental Psychology of the Centre of Social and Psychological \\ Sciences, Slovak Academy of Sciences, Dúbravská cesta 9, 84104 Bratislava, \\ Slovakia \\ martin.sedlar@savba.sk
}

\begin{abstract}
The study aims to map job stressors and job satisfaction in emergency medical services (EMS) crew members and to examine relationships between job stressors and job satisfaction. A research sample of 131 EMS crew members (physicians, paramedics, ambulance drivers, and one nurse) working in Slovakia completed selfreport questionnaires. The descriptive statistics revealed that the majority of participants were overall satisfied with working in EMS and for them the most bothersome stressors were working with a substandard co-employee on emergency incidents or situations, disruption of sleep, conflicts with co-workers and team members, financial strain due to inadequate pay, and feelings of isolation from family due to work demands and stress. According to the correlation analysis, the overall score of job stress was significantly negatively related to job satisfaction. Regarding individual stressors, poor diet, financial strain due to inadequate pay, dislike of routine paper work, disruption of sleep, and feelings of isolation from family due to work demands and stress were significantly negatively related to job satisfaction. These findings point out problematic elements of EMS work. They can serve as a stimulus for detailed follow-up research and what the Slovak EMS agencies should focus on in addressing the issues of job stress and job satisfaction among their employees providing prehospital emergency care.
\end{abstract}

Keywords: job stressors, job satisfaction, emergency medical services

\section{INTRODUCTION}

The level of self-reported job stress in emergency medical services (EMS) crew members belongs to the highest in comparison to other professions (Hammer et al., 1986; Johnson et al., 2005). Acute and chronic stress has a negative impact not only on EMS crew members' health (Halpern et al., 2011), but also on their skills and overall job performance (LeBlanc et al., 2012), which ultimately endangers the quality and safety of health care provided.

Research of Beaton et al. (1993) has suggested that stressors (i.e., sources of stress) in emergency services workers, whether they are from medical or fire services, are similar and can be grouped into 14 categories corresponding to a great extent with the following categories identified by Kimbrel et al. (2011): poor health habits, discrimination, management/labor conflict, financial concerns, lack of control, job skills concerns, past critical incidents, general stress, tedium/routine, substandard equipment/employees, co-worker conflict, sleep disturbance, family concerns, and apprehensions regarding personal safety. Regarding the listed categories, the most bothersome stressors among EMS workers have been considered mostly the ones referring to finance, 
management, critical incidents, personal safety, equipment, sleep disturbance, and co-employees (Beaton et al., 1993; Gurňáková, 2013; James et al., 1991; Kristová et al., 2009; Sterud et al., 2008; Šeblová et al., 2007). There are also other EMS stressors categorizations, which are slightly different, and which are discussed elsewhere (e.g., James et al., 1991; Sterud et al., 2008).

However, the majority of yet cited research on stressors in EMS has not addressed their linkage with job satisfaction. In fact, a negative relationship has been found between job satisfaction and overall job stress (Boudreaux et al., 1997; Kimbrel et al., 2011), specifically, between job satisfaction and management/labor conflicts, tedium/routine, sleep disturbance, and past critical incidents (Beaton et al., 1993).

The insufficient findings concerning the presented issues in Slovak EMS crew members (Gurňáková, 2013; Kristová et al., 2009) have given momentum to conduct this study. It aims to map job stressors and job satisfaction in EMS crew members working in Slovakia and to examine relationships between job stressors and job satisfaction.

\section{METHOD}

\subsection{Participants}

The research sample consists of 131 EMS crew members (72 men, 59 women), aged between 22 and 66 years $(M=37.53, S D=11.20)$, with practice in health care from 1 to 45 years $(M=15.57, S D$ $=11.41)$ and with practice in EMS from 1 to 40 years $(M=11.57, S D=8.78)$. All participants were from ground EMS crews: physicians $(n=18)$, paramedics $(n=108)$, ambulance drivers $(n=4)$ and one nurse working in EMS. In Slovakia, there are two basic types of ground EMS crews. Physicianled crews are composed of three members - a physician, a paramedic, and an ambulance driver. Paramedic-led crews are composed of two members - a paramedic and an ambulance driver. Paramedics with an ambulance driving license can work as drivers. Instead of paramedics, EMS crews can also be staffed by nurses with adequate education.

\subsection{Measures}

Job stressors were measured by the Sources of Occupational Stress-14 (Kimbrel et al., 2011). It is a questionnaire comprised of 14 items, of which each item is related to different categories described in the introduction section. This shortened questionnaire version was developed on a sample of firefighters based on the original 57-items questionnaire version developed on a sample of emergency services workers, providing both fire and medical services (Beaton et al., 1993). Participants rated each item on a 5-point scale $(1=$ does not bother me at all, $5=$ bothers me extremely), by which they expressed to what extent each job stressor bothers them (i.e., frustrates, annoys, irritates) in general (without any restriction to a specific time period). The internal reliability of the Slovak translation of the questionnaire was very good in this study ( $\alpha=$ 0.84), similar to the internal reliability in the previous studies (Kimbrel et al., 2011; Kimbrel et al., 2015). Both a calculation of an overall score of EMS workers' job stress and individual job stressors were used in the analysis.

Job satisfaction was measured by one question (How much are you satisfied overall with working in EMS?). Participants indicated their answers on a 5 -point scale (1 = very dissatisfied, 5 = very satisfied).

\subsection{Procedure}

The collection of data analyzed in this study was part of a larger data collection that was carried out online between March and December 2019 using Qualtrics and convenience sampling (email requests sent to EMS agencies and acquaintances from EMS, and posts shared in specific EMS- 
related Facebook groups). The research conditions (voluntariness, anonymousness) and the research aim were described at the beginning of the questionnaires battery. As an incentive, participants were offered a chance to win one of three $€ 50$ gift vouchers. To be included in the draw, the questionnaires had to be completed and the participants had to enter their email addresses. All participants gave informed consent to participate. Descriptive statistics and Spearman's correlation analysis were used for data analysis.

\section{RESULTS}

The descriptive statistics (Table 1) show that the most bothersome stressors were (in the following order): working with a substandard co-employee on emergency incidents or situations, disruption of sleep, conflicts with co-workers and team members, financial strain due to inadequate pay, and feelings of isolation from family due to work demands and stress. Less bothersome stressors were: observing negative effects of stress on co-workers, poor diet, dislike of routine paper work, concerns about serious personal injury/disablement/death due to work, exposure to anxious or overly demanding co-worker or administrator, thoughts about past run(s) that have been particularly upsetting/disturbing, bothered by not being able to predict or control events, and concerns about not knowing the latest technology. The least bothersome stressor was discrimination based on gender, ethnicity, or age.

Furthermore, it was revealed (Table 2) that the majority of EMS workers were overall satisfied or very satisfied with working in EMS. A smaller number of EMS workers were neither dissatisfied nor satisfied and the smallest number of EMS workers were dissatisfied or very dissatisfied.

According to the correlation analysis (Table 3), job satisfaction in EMS was significantly negatively associated with overall job stress and specifically with the following stressors: poor diet, financial strain due to inadequate pay, dislike of routine paper work, disruption of sleep, and feelings of isolation from family due to work demands and stress. All significant correlation coefficients were weak. Besides these main findings corresponding to the research aim, sociodemographic variables (gender, age, practice in EMS, and practice in health care) were analyzed and relevant results are presented in Table 3.

Table 1 Descriptive statistics of job stressors

\begin{tabular}{lccccccccc}
\hline Variable & $M$ & $S D$ & Mdn & Mo & \multicolumn{5}{c}{ Frequency in percent } \\
\cline { 6 - 11 } & & & & & 1 & 2 & 3 & 4 & 5 \\
\hline Poor diet. & 2.56 & 1.20 & 2.00 & 2 & 23.7 & 26.7 & 23.7 & 21.4 & 4.6 \\
\hline $\begin{array}{l}\text { Discrimination based on } \\
\text { gender, ethnicity, or age. }\end{array}$ & 1.96 & 1.20 & 1.00 & 1 & 50.4 & 21.4 & 14.5 & 9.2 & 4.6 \\
\hline $\begin{array}{l}\text { Exposure to anxious or } \\
\text { overly demanding co- } \\
\text { worker or administrator. }\end{array}$ & 2.37 & 1.15 & 2.00 & 2 & 23.7 & 37.4 & 24.4 & 6.9 & 7.6 \\
\hline $\begin{array}{l}\text { Financial strain due to } \\
\text { inadequate pay. }\end{array}$ & 2.92 & 1.15 & 3.00 & 3 & 10.7 & 27.5 & 30.5 & 21.4 & 9.9 \\
\hline $\begin{array}{l}\text { Bothered by not being } \\
\text { able to predict or control } \\
\text { events. }\end{array}$ & 2.08 & 0.94 & 2.00 & 2 & 30.5 & 38.9 & 22.9 & 6.9 & 0.8 \\
\hline $\begin{array}{l}\text { Concerns about not } \\
\text { knowing the latest }\end{array}$ & 2.06 & 1.04 & 2.00 & 2 & 35.1 & 37.4 & 16.0 & 9.2 & 2.3 \\
technology. & & & & & & & & \\
\hline
\end{tabular}


Pomáhajúce profesie, roč. 4, č. 2, 2021, 22-30

\begin{tabular}{|c|c|c|c|c|c|c|c|c|c|}
\hline $\begin{array}{l}\text { Thoughts about past } \\
\text { run(s) that have been } \\
\text { particularly } \\
\text { upsetting/disturbing. }\end{array}$ & 2.09 & 0.99 & 2.00 & 2 & 32.8 & 35.1 & 23.7 & 6.9 & 1.5 \\
\hline $\begin{array}{l}\text { Observing negative } \\
\text { effects of stress on co- } \\
\text { workers, e.g., illness, } \\
\text { alcohol abuse, and } \\
\text { burnout. }\end{array}$ & 2.63 & 1.15 & 2.00 & 2 & 15.3 & 37.4 & 24.4 & 15.3 & 7.6 \\
\hline $\begin{array}{l}\text { Dislike of routine paper } \\
\text { work. }\end{array}$ & 2.47 & 1.24 & 2.00 & 2 & 26.0 & 31.3 & 19.1 & 16.8 & 6.9 \\
\hline $\begin{array}{l}\text { Working with a } \\
\text { substandard co- } \\
\text { employee on emergency } \\
\text { incidents or situations. }\end{array}$ & 3.44 & 1.29 & 4.00 & 4 & 9.9 & 14.5 & 22.9 & 26.7 & 26.0 \\
\hline $\begin{array}{l}\text { Conflicts with co- } \\
\text { workers and team } \\
\text { members. }\end{array}$ & 3.01 & 1.21 & 3.00 & 3 & 12.2 & 23.7 & 26.7 & 26.0 & 11.5 \\
\hline Disruption of sleep. & 3.11 & 1.19 & 3.00 & 3 & 9.2 & 23.7 & 29.0 & 23.7 & 14.5 \\
\hline $\begin{array}{l}\text { Feelings of isolation from } \\
\text { family due to work } \\
\text { demands and stress. }\end{array}$ & 2.81 & 1.23 & 3.00 & 2 & 14.5 & 32.1 & 22.9 & 19.1 & 11.5 \\
\hline $\begin{array}{l}\text { Concerns about serious } \\
\text { personal } \\
\text { injury/disablement/deat } \\
\text { h due to work. }\end{array}$ & 2.40 & 1.24 & 2.00 & 2 & 27.5 & 34.4 & 17.6 & 12.2 & 8.4 \\
\hline
\end{tabular}

Note. 1 = does not bother me at all, 2 = bothers me a little, 3 = bothers me moderately, $4=$ bothers me a lot, 5 = bothers me extremely

Table 2 Descriptive statistics of job satisfaction

\begin{tabular}{lccccccccc}
\hline Variable & $M$ & $S D$ & $M d n$ & Mo & \multicolumn{4}{c}{ Frequency in percent } \\
\cline { 5 - 8 } & & & & & 1 & 2 & 3 & 4 & 5 \\
\hline Job satisfaction & 3.73 & 0.80 & 4.00 & 4 & 0.8 & 6.1 & 26.7 & 52.7 & 13.7 \\
\hline
\end{tabular}

Note. 1 = very dissatisfied, 2 = dissatisfied, 3 = neither dissatisfied nor satisfied, $4=$ satisfied, $5=$ very satisfied

Table 3 Spearman's correlation coefficients between overall job stress, stressors, job satisfaction, and sociodemographic variables

\begin{tabular}{llllll}
\hline Variable & $\begin{array}{c}\text { Job } \\
\text { satisfactio } \\
\mathrm{n}\end{array}$ & Gender & Age & $\begin{array}{c}\text { Practice in } \\
\text { EMS }\end{array}$ & $\begin{array}{c}\text { Practice in } \\
\text { HC }\end{array}$ \\
& $-.24^{* *}$ & .16 & -.13 & -.13 & -.10 \\
\hline Overall job stress & $-.18^{*}$ & -.01 & $-.44^{* * *}$ & $-.38^{* * *}$ & $-.40^{* * *}$ \\
\hline Poor diet. & -.11 & $.22^{*}$ & -.13 & -.07 & -.07 \\
\hline $\begin{array}{l}\text { Discrimination based on } \\
\text { gender, ethnicity, or age. }\end{array}$ & -.15 & .12 & .02 & -.03 & .02 \\
\hline $\begin{array}{l}\text { Exposure to anxious or } \\
\text { overly demanding co- }\end{array}$ & & & & & \\
$\begin{array}{l}\text { worker or administrator. } \\
\text { vadman }\end{array}$ & & & & &
\end{tabular}


Pomáhajúce profesie, roč. 4, č. 2, 2021, 22-30

\begin{tabular}{|c|c|c|c|c|c|}
\hline $\begin{array}{l}\text { Financial strain due to } \\
\text { inadequate pay. }\end{array}$ & $-.27^{* *}$ & -.04 & $-.24^{* *}$ & $-.23^{* *}$ & $-.21 *$ \\
\hline $\begin{array}{l}\text { Bothered by not being able } \\
\text { to predict or control events. }\end{array}$ & -.13 & $.23^{* *}$ & -.04 & -.14 & -.06 \\
\hline $\begin{array}{l}\text { Concerns about not knowing } \\
\text { the latest technology. }\end{array}$ & -.01 & $.22^{*}$ & .06 & -.04 & .03 \\
\hline $\begin{array}{l}\text { Thoughts about past run(s) } \\
\text { that have been particularly } \\
\text { upsetting/disturbing. }\end{array}$ & .02 & $.21 *$ & .17 & .14 & $.22 *$ \\
\hline $\begin{array}{l}\text { Observing negative effects of } \\
\text { stress on co-workers, e.g., } \\
\text { illness, alcohol abuse, and } \\
\text { burnout. }\end{array}$ & -.05 & .15 & -.05 & -.09 & -.08 \\
\hline $\begin{array}{l}\text { Dislike of routine paper } \\
\text { work. }\end{array}$ & $-.20^{*}$ & $-.23^{* *}$ & -.04 & -.05 & -.02 \\
\hline $\begin{array}{l}\text { Working with a substandard } \\
\text { co-employee on emergency } \\
\text { incidents or situations. }\end{array}$ & -.08 & .03 & .04 & .09 & .05 \\
\hline $\begin{array}{l}\text { Conflicts with co-workers } \\
\text { and team members. }\end{array}$ & -.14 & .08 & -.09 & -.11 & -.10 \\
\hline Disruption of sleep. & $-.23^{* *}$ & .04 & -.09 & -.05 & -.03 \\
\hline $\begin{array}{l}\text { Feelings of isolation from } \\
\text { family due to work demands } \\
\text { and stress. }\end{array}$ & $-.24^{* *}$ & .17 & -.12 & -.11 & -.08 \\
\hline $\begin{array}{l}\text { Concerns about serious } \\
\text { personal } \\
\text { injury/disablement/death } \\
\text { due to work. }\end{array}$ & -.08 & .13 & -.02 & -.02 & .02 \\
\hline Job satisfaction & - & .13 & $.18^{*}$ & .15 & .16 \\
\hline
\end{tabular}

Note. EMS = emergency medical services; $\mathrm{HC}=$ health care; gender coded as 1 for men and 2 for women; age and practice in EMS and HC are in years; ${ }^{*} \mathrm{p}<.05$; $^{* *} \mathrm{p}<.01 ;{ }^{* * *} \mathrm{p}<.001$.

\section{DISCUSSION}

The study aimed to map job stressors and job satisfaction and to examine their relationships in Slovak EMS crew members. The results showed that most of the participants were satisfied with working in EMS, only a very low percentage was dissatisfied. A possible explanation of this finding is that many EMS workers can usually choose and remain in their profession based on a sense of mission and a desire to help others - the profession itself provides them meaning in life along with job satisfaction (Dopelt et al., 2019). Consistent with other studies (Boudreaux et al., 1997; Kimbrel et al., 2011), a weak negative relationship between overall job stress and job satisfaction in EMS was also found. However, the analysis focused on specifics - individual stressors and their relationships with job satisfaction - highlights some problems in EMS.

In general, several most bothersome stressors were identified. Two of them referred to co-workers, namely, working with substandard co-employee on emergency incidents or situations, and conflicts with co-workers and team members. Similar problems with co-workers emerged as being quite stressful in other research (James et al., 1991; Sterud et al., 2008). This suggests that coworkers are perceived as an important part of their job. Actually, all co-workers in an EMS crew 
need each other to cooperate and use their social skills to manage emergency situations (Kaššaiová, 2020), otherwise, there is an increased risk of not managing emergency situations well, effectively, and safely. Other most bothersome stressors were disruption of sleep and financial strain due to inadequate pay - this is in line with the research on emergency services personnel (Beaton et al., 1993; James et al., 1991). It is known that sleep disruption and other problems connected to sleep have various negative health (Medic et al., 2017) and performance consequences (Patterson et al., 2012). From this perspective, it is not surprising that being more bothered by sleep disruption weakly correlated with lower job satisfaction in EMS workers - the same result as in the previous study (Beaton et al., 1993). Inadequate pay is a potential serious reason for quitting a job in EMS (Dopelt et al., 2019; Rivard et al., 2020) and can be considered a significant factor of job dissatisfaction, because the more bothersome the inadequate pay was for EMS workers, the less satisfied they were with the job. It must be noted that among investigated stressors, inadequate pay had the strongest significant negative relationship with job satisfaction, but from the statistical point of view, it is still classified as a weak relationship. The analysis revealed three more stressors that are worth mentioning. Feelings of isolation from family due to work demands and stress were considered quite bothersome and weakly correlated with lower job satisfaction. Experiencing such feelings can indicate worse work-life balance and coping mechanisms. In compliance with the finding (Beaton et al., 1993), dislike of routine paper work emerged as the stressor weakly associated with lower job satisfaction, even though it was bothersome only a little for EMS workers. Probably, paper work, such as filling in the required documentation about a patient, becomes more bothersome in critical situations in which life-saving interventions are the main goal. Lastly, despite expectations, poor diet was weakly negatively associated with job satisfaction. In other words, EMS workers may sometimes tend to feel dissatisfaction in their work when they do not have high quality diet - this can be due to their poor health habits or their employers who do not ensure healthy diet. In addition to the presented findings, the analysis suggested that job satisfaction and job stressors were also related to age, gender, and practice.

The limitations of this study are an unrepresentative sample and using methods that could not capture the comprehensiveness of the investigated topics - however, this was not the study's aim. Moreover, the method measuring stressors was developed based on the research of firefighters, therefore, it may not be completely and exactly applicable for the research of EMS workers. After all, this method measures the extent to which stressors are bothersome and does not measure the frequency of the stressors occurrence. All the mentioned deficiencies should be taken into account in conducting more detailed follow-up studies.

\section{CONCLUSION}

The study's contribution lies in providing findings on a Slovak sample of EMS crew members. It revealed the predominance of satisfaction with working in EMS and brought an overview of some problematic elements of EMS work in terms of which specific stressors were the most bothersome and which specific stressors were related to job satisfaction. These specific stressors fall into the predefined general stressors categories (Kimbrel et al., 2011), such as poor health habits, financial concerns, tedium/routine, substandard equipment/employees, co-worker conflict, sleep disturbance, and family concerns. In the scientific field, the trend of classifying specific stressors into general categories is quite apparent and useful - it enables conceptual understanding of stressors within a particular profession, which is not enabled by presenting a simple list of stressors. Unlike stressors tightly connected with the nature of the EMS job that cannot be changed, such as encountering critical incidents and not being able to completely predict or control events, the good news is that the discussed stressors and related dissatisfaction can be mitigated. Thus, 
the findings can serve as a stimulus for what the Slovak EMS agencies and their employees providing frontline emergency care should focus on in addressing these issues.

\section{REFERENCES}

Beaton, R. D., \& Murphy, S. A. (1993). Sources of occupational stress among firefighter/EMTs and firefighter/paramedics and correlations with job-related outcomes. Prehospital and Disaster Medicine, 8(2), 140-150. https://doi.org/10.1017/S1049023X00040218

Boudreaux, E., Mandry, C., \& Brantley, P. J. (1997). Stress, job satisfaction, coping, and psychological distress among emergency medical technicians. Prehospital and Disaster Medicine, 12(4), 9-16. https://doi.org/10.1017/S1049023X00037742

Dopelt, K., Wacht, O., Strugo, R., Miller, R., \& Kushnir, T. (2019). Factors that affect Israeli paramedics' decision to quit the profession: A mixed methods study. Israel Journal of Health Policy Research, 8:78. https://doi.org/10.1186/s13584-019-0346-0

James, A. E., \& Wright, P. L. (1991). Occupational stress in the ambulance service. Journal of Managerial Psychology, 6(3), 13-22. https://doi.org/10.1108/02683949110001727

Johnson, S., Cooper, C., Cartwright, S., Donald, I., Taylor, P., \& Millet, C. (2005). The experience of work-related stress across occupations. Journal of Managerial Psychology, 20(2): 178-187. https://doi.org/10.1108/02683940510579803

Gurňáková, J. (2013). Zdroje akútneho a chronického stresu v práci zdravotníckych profesionálov [Origins of acute and chronic stress in the work of medical professionals]. In Gurňáková J.et al., Rozhodovanie profesionálov: Sebaregulácia, stres a osobnost' [Decision making of professionals: Self-regulation, stress and personality] (pp. 33-68). ÚEP SAV.

Halpern, J., \& Mauder. R. G. (2011). Acute and chronic workplace stress in emergency medical technicians and paramedics. In J. Langan-Fox \& C. L. Cooper (Eds.), Handbook of stress in the occupations (pp. 135-156). Edward Plgar Publishing. https://doi.org/10.4337/9780857931153.00024

Hammer, J. S., Mathews, J. J., Lyons, J. S., \& Johnson, N. J. (1986). Occupational stress within the paramedic profession: An initial report of stress levels compared to hospital employees. Annals of Emergency Medicine, 15(5), 536-539. https://doi.org/10.1016/S0196-0644(86)80988-X

Kaššaiová, Z. (2020). Social skills for paramedics in Slovakia. Človek a spoločnost', 23(2), 29-42. http://doi.org/10.31577/cas.2020.02.572

Kimbrel, N. A., Steffen, L. E., Meyer, E. C., Kruse, M. I., Knight, J. A., Zimering, R. T., \& Gulliver, S. B. (2011). A revised measure of occupational stress for firefighters: Psychometric properties and relationship to posttraumatic stress disorder, depression, and substance abuse. Psychological Services, 8(4), 294-306. https://doi.org/10.1037/a0025845

Kimbrel, N. A., Flynn, E. J., Carpenter, G. S. J., Cammarata, C. M., Leto, F., Ostiguy, W. J., ... \& Gulliver, S. B. (2015). Internal consistency, test-retest reliability, and predictive validity for a Likert-based version of the Sources of occupational stress-14 (SOOS-14) scale. Psychiatry Research, 228(3), 961962. https://doi.org/10.1016/j.psychres.2015.05.031

Kristová, J., Zvalová, D., \& Musilová, E. (2009). Stresogénne podnetové situácie v povolaní zdravotníckeho záchranára [Stressogenic motivational situations in paramedics]. Ošetrovatel'ský obzor, 6(2), 45-49. 
LeBlanc, V. R., Regehr, C., Tavares, W., Scott, A. K., MacDonald, R., \& King, K. (2012). The impact of stress on paramedic performance during simulated critical events. Prehospital and Disaster Medicine, 27(4), 369-374. https://doi.org/10.1017/S1049023X12001021

Medic, G., Wille, M., \& Hemels, M. E. (2017). Short- and long-term health consequences of sleep disruption. Nature and Science of Sleep, 9, 151-161. https://doi.org/10.2147/NSS.S134864

Patterson, P. D., Weaver, M. D., Frank, R. C., Warner, C. W., Martin-Gill, C., Guyette, F. X., ... \& Hostler, D. (2012). Association between poor sleep, fatigue, and safety outcomes in emergency medical services providers. Prehospital Emergency Care, 16(1), 86-97. https://doi.org/10.3109/10903127.2011.616261

Rivard, M. K., Cash, R. E., Woodyard, K. C., Crowe, R. P., \& Panchal, A. R. (2020). Intentions and motivations for exiting the emergency medical services profession differ between emergency medical technicians and paramedics. Journal of Allied Health, 49(1), 53-59.

Sterud, T., Hem, E., Ekeberg, Ø., \& Lau, B. (2008). Occupational stressors and its organizational and individual correlates: a nationwide study of Norwegian ambulance personnel. BMC Emergency Medicine, 8:16. https://doi.org/10.1186/1471-227X-8-16

Šeblová, J., Kebza, V., \& Vignerová, J. (2007). Zátěž a stres pracovníků záchranných služieb v České republice: Expozice kritickým událostem a výskytu syndromu vyhoření v letech 2003-2005 [Load and stress in workers of emergency medical services in the Czech Republic: Exposition to critical events and burn-out sydrome occurence in 2003-2005]. Českolovenská Psychologie, 51(4), 404417.

\section{PRACOVNÉ STRESORY A PRACOVNÁ SPOKOJNOSŤ U ČLENOV POSÁDOK ZÁCHRANNEJ ZDRAVOTNEJ SLUŽBY NA SLOVENSKU}

Abstrakt: Ciel'om štúdie je zmapovanie pracovných stresorov a pracovnej spokojnosti u členov posádok záchrannej zdravotnej služby (ZZS), ako aj zistenie vzt’ahov medzi pracovnými stresormi a pracovnou spokojnost'ou. Výskumný súbor tvorilo 131 členov posádok ZZS (lekári, zdravotnícki záchranári, vodiči ambulancií, a jedna sestra), ktorí vyplnili sebavýpoved'ové dotazníky. Deskriptívna štatistika odhalila, že väčšina participantov bola celkovo spokojná s prácou v ZZS a najviac zat’ažujúce stresory boli pre nich práca s podpriemerným spolupracovníkom v záchranárskych situáciách, narušenie spánku, konflikty so spolupracovníkmi a členmi tímu, finančné t’ažkosti spôsobené nedostatočným platom a pocity izolácie od rodiny v dôsledku pracovných požiadaviek a stresu. Podl'a výsledkov korelačnej analýzy celkové skóre pracovného stresu signifikantne negatívne súviselo s pracovnou spokojnost'. Z hl'adiska jednotlivých stresorov signifikantne negatívne súviseli s pracovnou spokojnost'ou slabá strava, finančné t’ažkosti spôsobené nedostatočným platom, odpor k rutinnej administratívnej práci, narušenie spánku a pocity izolácie od rodiny v dôsledku pracovných požiadaviek a stresu. Tieto zistenia poukazujú na problematické elementy práce v ZZS. Môžu slúžit’ ako podnet pre nasledovný detailnejší výskum a ako náčrt toho, na čo by sa mali slovenskí poskytovatelia ZZS sústredit' pri riešení otázok pracovného stresu a pracovnej spokojnosti u svojich zamestnancov zabezpečujúcich prednemocničnú neodkladnú zdravotnú starostlivost'.

Kl'účové slová: pracovné stresory, pracovná spokojnost', záchranná zdravotná služba 


\section{Acknowledgements}

The author would especially like to thank Veronika Marečková for her help with this research. The author designed the research and was the only manuscript contributor; however, Veronika Marečková participated in the translation of questionnaires and the data collection, as part of the data were used in her master's thesis.

This work was supported by the Scientific Grant Agency of the Ministry of Education, Science, Research and Sport of the Slovak Republic and Slovak Academy of Sciences [Grant No. VEGA 2/0070/18, 'Cognitive and Social Skills Supporting Decision Making and the Quality of Performance of Emergency Medical Services Crew Members'].

\section{Ethics approval and consent to participate}

The entire Grant No. VEGA 2/0070/18 has been reviewed and received a Favourable Opinion from the Ethics Committee of the Slovak Academy of Sciences, Bratislava, Slovakia. Each participant gave informed consent to participate in the study.

\section{Disclosure statement}

No potential conflict of interest was reported by the author. 